\title{
RISK-TAKING BEHAVIOR IN RECOVERED COVID-19 PATIENTS
}

\author{
Aslı Egeli ${ }^{1}$, Serkan Adıgüzel ${ }^{2}$, Yaşar Kapıcı ${ }^{1}$, Bulut Güc ${ }^{1}$, Ayşegül Yetkin Tekin ${ }^{3}$ \& Atilla Tekin ${ }^{1}$ \\ ${ }^{1}$ Psychiatry Department, Faculty of Medicine, Adiyaman University, Adiyaman, Turkey \\ ${ }^{2}$ Psychology Department, Faculty of Art and Sciences, Haliç University, İstanbul, Turkey \\ ${ }^{3}$ Private Psychological Counselor, Adlyaman, Turkey
}

received: 13.12.2020;

revised: 26.2.2021;

accepted: 2.3 .2021

\begin{abstract}
SUMMARY
Background: The aim of this study is to investigate risk-taking behavior and decision-making processes in recovered COVID19 patients.

Subjects and methods: Twenty patients recovered from COVID-19 as confirmed by polymerase chain reaction (PCR) tests and twenty-one healthy individuals were recruited. A computerized version of the Iowa Gambling Test (IGT) for measuring risk-taking behavior tendencies as a decision-making process and State-Trait Anxiety Inventory (STAI), Beck Depression Inventory (BDI), and WMS-R Digit Span Forward Test (DSFT) for clinical assessments included. The assessments of the recovered patients were applied on the initial phase that the tests of the patients were negative and on the 4-week follow up phase.

Results: The results showed that the anxiety scores were significantly higher in the healthy control group than in the group of recovered patients. The IGT-Net 4 scores were significantly and IGT-Net total scores were marginally significantly lower in the group of recovered patients. In other words, recovered patients showed higher risk-taking behavior tendencies. This tendency difference is consistent with the anxiety levels of the groups. These IGT scores showed to be persistent in the 4-week follow up phase.

Conclusions: Our findings indicate that recovered patients show higher risk-taking behavior tendencies than healthy controls and this may be the result of overcoming the COVID-19 threat.
\end{abstract}

Key words: COVID-19 - Iowa gambling task - risk-taking behavior - decision-making

\section{INTRODUCTION}

Corona Virus Disease 2019 (COVID-19) is a highly infectious disease and its effects are seen almost all over the world. From the time that the first case reported, numbers have reached huge amounts with almost 40 million cases and 1.1 million of deaths (World Health Organization 2020). Due to its high contagious and mortality risks, it became a public health emergency of international concern. These high-risk factors led this epidemic to have impacts on many different areas. To start with the social impacts, social distancing, working from home, and distance learning are new ways of living our lives while risk for agriculture and food, travel restrictions, and curfews are our new concerns. Regarding the economic impacts, we are facing employment shock, extreme fall in trade and commodity prices, manufacturing declines, and vulnerabilities in banking systems. When the impacts on health are considered, the primary effects of COVID-19 are obvious but not surprisingly mental health is also highly affected during this epidemic (International Labor Organization 2020).

The psychological impact of the epidemic is studied by several pieces of research. A research conducted by Yang and Ma (2020) showed that the epidemic led to a $74 \%$ drop in overall emotional well-being. Also, impacts on depressive and anxious symptoms (Haji Akhoundi et al. 2020, Li et al. 2020, Luo et al. 2020, Wang et al. 2020, Wang et al. 2020), severe stress levels (Wang et al. 2020) and decrease in positive emotions and life satisfaction ( $\mathrm{Li}$ et al. 2020) have been reported. Reactive psychosis and mood alterations due to neuroinflammation in patients with COVID-19 have been reported (Lazzari et al. 2020, Sinanovic et al. 2020, ValdésFlorido et al. 2020, Van Rheenen et al. 2020). When we consider the cognitive effects, Haji Akhoundi et al. (2020) showed a cognitive dysfunction up to $70 \%$ in multiple sclerosis patients. A lower correct number and reaction time score in the Continuous Performance Test is also reported in COVID-19 patients (Zhou et al. 2020).

All in all, the epidemic has affected our lives in many ways. Decision-making strategies and risk-taking behavior may be one of them. Behaviors that increase the probability of developing a physical, social, and psychological problem as a result are called risk-taking behavior. Such behaviors can be sampling as smoking and drinking alcohol, insecure sexual relationship, reckless driving, and extreme sports (Byrnes 2003). Risktaking behavior tendency shows differences according to gender (Bayar \& Sayil 2005, Singh et al. 2020), age (Bayar \& Sayil 2005), parents' attitude, and social connections (Uludağlı \& Sayıl 2009). Another affecting factor is cognitional and emotional abnormalities which have strong empirical support (Guven 2012, Kusev et al. 2009). Accordingly, accessibility to decision-making contents and having emotion regulation strategies have an impact on risk preferences and tendencies.

In this context, the aim of this study is to investigate risk-taking behavior tendencies in recovered COVID-19 patients. Although a full neuropsychological evaluation is needful to reveal this tendency, the Iowa Gambling Test is shown to be a reliable tool (Bechara et al. 2005, 
Giustiniani et al. 2019, Icellioglu 2015, Li et al. 2010, Miu et al. 2008). The importance of this study is to clarify the potential difference in recovered COVID-19 patients' risk-taking behavior tendencies via an objective measurement. In doing so, the experimental group consists of the patients unlike many other pieces of research in the literature. So, the cognitive impairment and behavioral changes that result from the epidemic would be able to be investigated.

\section{SUBJECTS AND METHODS}

\section{Participants}

Using a convenience sampling method, 20 recovered patients aged 19-56 who were formerly diagnosed with COVID-19 (38.3 \pm 12 years) and 21 healthy individuals aged 22-56 (37.4 \pm 9 years) were recruited from Adiyaman University Training and Research Hospital. All participants had full physical and mental health, were not addicted to any drugs and alcohol. Additionally, all participants were free of brain tumor, trauma, and surgery. All procedures performed in this study were conducted with the informed consent of the participants.

The research protocol was registered in the clinical trials registry of the Turkish Ministry of Health and the non-invasive clinical research ethics committee of Adiyaman University (Registration Number: 2020/5-7).

\section{Experimental Tasks}

\section{State-Trait Anxiety Inventory}

The State-Trait Anxiety Inventory (STAI) is a likert type scale consisting of 40 questions and developed by Spielberger et al. (1970). This scale consists of two sections, each consisting of 20 questions, and these sections measure state and trait anxiety levels separately. While the State Anxiety Inventory (SAI) is sensitive to changes in the instantaneous anxiety level, the Trait Anxiety Inventory (TAI) is sensitive to changes in the general anxiety level. The total score for both sections varies between 20 and 80 scores. Higher scores indicate higher anxiety status. With the implementation of the STAI, it was aimed to evaluate the state anxiety levels of patients continuously and trait anxiety levels before the pandemic outcome and their possible overall effects on risk-taking behavior. The validity and reliability study of the Turkish form was conducted by Öner and Le Compte (1983).

\section{Beck Depression Inventory}

Beck Depression Inventory (BDI) is a likert type scale developed by Beck (1961) and consisting of 21 questions. These questions are prepared to include the symptoms seen in depression based on clinical observation. Each question is rated with values ranging from 0-3 scores. Accordingly, the scale score ranges from 0 to 63 scores. Higher scores indicate higher levels of depression. The purpose of applying BDI in the study is to evaluate the depression levels of patients and their possible effects on risk-taking behavior. The validity and reliability study of the Turkish form was conducted by Hisli (1989).

\section{WMS-R Digit Span Forward Test}

The Digit Span Forward Test (DSFT) is a subtest of the Wechsler Memory Scale and is dedicated to measuring memory for digits (Wechsler 1939). There are two types of digit span tests as digit span forward and backward, and these tests can be applied both verbally and visually. In the digit span forward test, a series of random single digits are either read or shown to the participant and then expected to recall them in order. This test is used to examine participants' shortterm memory capacities and attention abilities. The validity and reliability study of the Turkish form were conducted by Karakas and Yalin (1995).

\section{The Iowa Gambling Task}

Iowa Gambling Task (IGT) is a neuropsychological test designed to reveal decision-making skills or deficiencies (Bechara et al. 1994). The Turkish norm study of IGT was conducted by Icellioglu (2015). A computerized version of IGT is used in this study. Initially, the participants are given 2000 points and are asked to choose from four decks of cards. The purpose of these choices is to increase the money owned at the end of the game as much as possible. These decks are made up of two types, which have an extremely high risk of loss which yields a high gain but ultimately can lead to a net loss, also called as disadvantaged decks and a smaller risk of loss and low gain but ultimately can lead to a net gain, also called as advantageous decks. During the task, we expect the participants to notice this distinction in the decks and create a tendency in their preferences. Thus, we can obtain information of the risk-taking behavior of the participants. After the participant chooses 100 cards, the test is concluded and their scores are calculated. Lower scores indicate a high risk-taking tendency while higher scores indicate low.

\section{Procedure}

The study design had two phases as initial and follow up, and two groups as experimental and control. For the experimental group, all processes are carried out on the day that patients are free of COVID-19 diagnosis. Despite this, during the process, all the COVID-19 precautions are considered and the application room had been made suitable for experimentation. In the initial phase, participants for both groups are provided with written informed consent. Then, all the participants were controlled for exclusion criteria. The clinical measures of STAI, BDI, WMS-R Digit Span Forward Test were applied in order. After all, a computerized version of IGT, the main outcome assessment of this study, was carried out. In the follow-up phase, for the experimental group, all the assessments were reapplied 4 weeks after the initial assessment day. 


\section{Statistical Analyses}

The SPSS software version 25.0 package program was used for statistical analyses of the present study. Normality distribution of the continuous variables was tested with their skewness and kurtosis values. The variables with skewness and kurtosis values between +1.5 and -1.5 were considered to fit the normal distribution. Comparisons of the categorical variables in patients and healthy controls were assessed with the ChiSquare and Fischer's Exact tests. Group comparisons of the variables that fitted normal distribution were evaluated with independent samples t-test. Group comparisons of the variables that do not show normal distribution were evaluated with the Mann-Whitney U test. Baseline and one-month follow-up tests and scales scores of the experimental group were compared with the Wilcoxon Signed Ranks test. The significance level was accepted as $\mathrm{p}<0.05$ for all tests.

\section{RESULTS}

\section{Demographic characteristics}

20 recovered patients who were formerly diagnosed with COVID-19 and 21 healthy controls included at the initial phase of the current study. 4 of the recovered patients dropped out at the follow-up phase.

Group comparisons for sociodemographic features were presented at Table-1. There were no significant differences between groups on age $(\mathrm{t}=0.261, \mathrm{p}=0.795)$, gender $\left(\chi^{2}=0.631, p=0.427\right)$, education $(p=0.076)$, occupation $(\mathrm{p}=0.261)$ and marital status $\left(\chi^{2}=0.013\right.$, $\mathrm{p}=0.910)$.

\section{Clinical Assessments}

BDI, DSFT, STAI and IGT scores of groups were compared at Table-2. Accordingly, DSFT scores in the experimental group were higher than healthy controls $(\mathrm{t}=-2.990, \mathrm{p}=0.005)$. State and trait anxiety scores of healthy controls were also higher than recovered patients' scores $(\mathrm{t}=-2.652, \mathrm{p}=0.012$ and $\mathrm{t}=-3.025, \mathrm{p}=0.004$, respectively). Mean rank of IGT-Net 4 scores in experimental group was higher compared to the healthy controls $(Z=-2.604, p=0.009)$. There were no statistical differences between groups on BDI $(\mathrm{t}=-1.943$, $\mathrm{p}=0.059)$, IGT-Net $1(\mathrm{Z}=-0.978, \mathrm{p}=0.328)$, IGT-Net 2 $(\mathrm{Z}=-0.762, \mathrm{p}=0.446)$, IGT-Net $3(\mathrm{Z}=-0.866, \mathrm{p}=0.387)$, IGT-Net $5(Z=-0.760, p=0.447)$ and IGT-Net Total scores $(Z=-1.963, p=0.05)$.

Table-1. Comparison of sociodemographic features between recovered COVID-19 patients and healthy controls

\begin{tabular}{|c|c|c|c|c|c|}
\hline Variable & & $\begin{array}{c}\text { COVID-19 }(+)(\mathrm{n}=20) \\
\mathrm{M} \pm \mathrm{SD} \text { or } \mathrm{n}(\%)\end{array}$ & $\begin{array}{c}\text { COVID-19 }(-)(\mathrm{n}=21) \\
\mathrm{M} \pm \mathrm{SD} \text { or } \mathrm{n}(\%)\end{array}$ & $t / \chi^{2}$ & $\mathrm{p}$ \\
\hline Age & & $38.3 \pm 12$ & $37.4 \pm 9$ & 0.261 & 0.795 \\
\hline \multirow[t]{2}{*}{ Age Group } & $18-40$ & $10(50)$ & $14(66.7)$ & 1.172 & 0.279 \\
\hline & $>40$ & $10(50)$ & $7(33.3)$ & & \\
\hline Gender (Female) & & $8(40)$ & $11(52.4)$ & 0.631 & 0.427 \\
\hline Education (University) & & $7(35)$ & $14(66.7)$ & & $0.076^{*}$ \\
\hline Occupation (Working) & & $10(50)$ & $16(76.2)$ & & $0.261 *$ \\
\hline Marital Status (Married) & & $13(65)$ & $14(66.7)$ & 0.013 & 0.910 \\
\hline
\end{tabular}

Abbreviations and Symbols: M: mean; SD: standart deviation; $\mathrm{n}$ : number; \%: percent; $\mathrm{t}$ : $\mathrm{t}$ score for indepent sample $\mathrm{t}$ test; $\chi 2$ : Pearson Chi-Square value; *: Fischer's Exact test

Table-2. Comparison of BDI, Digit Span Test, STAI and IOWA scores between recovered COVID-19 patients and healthy controls

\begin{tabular}{|c|c|c|c|c|}
\hline Test or Scale & $\begin{array}{l}\text { COVID-19 }(+)(n=20) \\
\text { M } \pm \text { SD or MR }(\text { SoR })\end{array}$ & $\begin{array}{l}\text { COVID-19 }(-)(n=21) \\
M \pm S D \text { or MR }(\text { SoR })\end{array}$ & $\mathrm{t} / \mathrm{Z}$ & $\mathrm{p}$ \\
\hline BDI & $8.7 \pm 7.6$ & $13.1 \pm 7.1$ & -1.943 & 0.059 \\
\hline Digit Span Test & $5.6 \pm 1.4$ & $6.9 \pm 1.3$ & -2.990 & 0.005 \\
\hline STAI- (State Anxiety) & $32.8 \pm 10.1$ & $40.4 \pm 8.1$ & -2.652 & 0.012 \\
\hline STAI- (Trait Anxiety) & $38.5 \pm 6.7$ & $45.3 \pm 7.8$ & -3.025 & 0.004 \\
\hline IGT-Net 1 & $22.85(457)$ & $19.24(404)$ & -0.978 & 0.328 \\
\hline IGT-Net 2 & $19.60(392)$ & $22.33(469)$ & -0.762 & 0.446 \\
\hline IGT-Net 3 & $19.38(387.5)$ & $22.55(473.5)$ & -0.866 & 0.387 \\
\hline IGT-Net 4 & $16.15(323)$ & $25.62(538)$ & -2.604 & 0.009 \\
\hline IGT-Net 5 & $19.60(392)$ & $22.33(469)$ & -0.760 & 0.447 \\
\hline IGT-Net Total & $17.25(345)$ & $24.57(516)$ & -1.963 & 0.050 \\
\hline
\end{tabular}

Abbreviations and Symbols: M: mean; SD: standart deviation; MR: mean rank; SoR: sum of ranks; $t$ : $t$ value for indepent sample t test; Z: Z value for Mann-Whitney U test 
Table-3. Comparison of initial and one-month follow-up BDI, Digit Span Test, STAI and IOWA test scores in recovered COVID-19 patients

\begin{tabular}{|c|c|c|c|c|c|}
\hline Test or Scale & & MR & SoR & $\mathrm{Z}$ & $\mathrm{p}$ \\
\hline BDI & $\begin{array}{l}\text { Negative Ranks }(\mathrm{N}=7) \\
\text { Positive Ranks }(\mathrm{N}=5)\end{array}$ & $\begin{array}{l}6.50 \\
6.50\end{array}$ & $\begin{array}{l}45.5 \\
32.5\end{array}$ & -0.513 & 0.608 \\
\hline STAI (State) & $\begin{array}{l}\text { Negative Ranks }(\mathrm{N}=8) \\
\text { Positive Ranks }(\mathrm{N}=8)\end{array}$ & $\begin{array}{l}8.06 \\
8.94\end{array}$ & $\begin{array}{l}64.5 \\
71.5\end{array}$ & -0.181 & 0.856 \\
\hline STAI (Trait) & $\begin{array}{l}\text { Negative Ranks }(\mathrm{N}=11) \\
\text { Positive Ranks }(\mathrm{N}=5)\end{array}$ & $\begin{array}{l}8.05 \\
9.50\end{array}$ & $\begin{array}{l}88.5 \\
47.5\end{array}$ & -1.061 & 0.289 \\
\hline Digit Span Test & $\begin{array}{l}\text { Negative Ranks }(\mathrm{N}=3) \\
\text { Positive Ranks }(\mathrm{N}=9)\end{array}$ & $\begin{array}{l}8.83 \\
5.72\end{array}$ & $\begin{array}{l}26.5 \\
51.5\end{array}$ & -1.016 & 0.310 \\
\hline IGT-Net 1 & $\begin{array}{l}\text { Negative Ranks }(\mathrm{N}=6) \\
\text { Positive Ranks }(\mathrm{N}=7)\end{array}$ & $\begin{array}{l}6.33 \\
7.57\end{array}$ & $\begin{array}{l}38.0 \\
53.0\end{array}$ & -0.529 & 0.597 \\
\hline IGT-Net 2 & $\begin{array}{l}\text { Negative Ranks }(\mathrm{N}=6) \\
\text { Positive Ranks }(\mathrm{N}=7)\end{array}$ & $\begin{array}{l}6.92 \\
7.07\end{array}$ & $\begin{array}{l}41.5 \\
49.5\end{array}$ & -0.290 & 0.771 \\
\hline IGT-Net 3 & $\begin{array}{l}\text { Negative Ranks }(\mathrm{N}=5) \\
\text { Positive Ranks }(\mathrm{N}=7)\end{array}$ & $\begin{array}{l}6.40 \\
6.57\end{array}$ & $\begin{array}{l}32.0 \\
46.0\end{array}$ & -0.553 & 0.580 \\
\hline IGT-Net 4 & $\begin{array}{l}\text { Negative Ranks }(\mathrm{N}=5) \\
\text { Positive Ranks }(\mathrm{N}=5)\end{array}$ & $\begin{array}{l}6.20 \\
4.80\end{array}$ & $\begin{array}{l}31.0 \\
24.0\end{array}$ & -0.365 & 0.715 \\
\hline IGT-Net 5 & $\begin{array}{l}\text { Negative Ranks }(\mathrm{N}=6) \\
\text { Positive Ranks }(\mathrm{N}=5)\end{array}$ & $\begin{array}{l}6.00 \\
6.00\end{array}$ & $\begin{array}{l}36.0 \\
30.0\end{array}$ & -0.269 & 0.788 \\
\hline IGT-Net Total & $\begin{array}{l}\text { Negative Ranks }(\mathrm{N}=6) \\
\text { Positive Ranks }(\mathrm{N}=9)\end{array}$ & $\begin{array}{l}8.42 \\
7.72 \\
\end{array}$ & $\begin{array}{l}50.5 \\
69.5 \\
\end{array}$ & -0.543 & 0.587 \\
\hline
\end{tabular}

Abbreviations and Symbols: MR: mean rank; SoR: sum of ranks ; Z: Z value for Wilcoxon Signed Ranks Test

Table-4. Comparison of BDI, Digit Span Test, STAI and IOWA scores between in participants aged 18-40 and over the age of 40 with and without COVID-19

\begin{tabular}{|c|c|c|c|c|}
\hline Test or Scale & $\begin{array}{c}\text { COVID-19 }(+)(n=10) \\
M \pm S D \text { or MR }(\text { SoR })\end{array}$ & $\begin{array}{l}\text { COVID-19 }(-)(n=14) \\
M \pm S D \text { or MR }(\text { SoR })\end{array}$ & $t / Z$ & $\mathrm{p}$ \\
\hline \multicolumn{5}{|l|}{ Aged 18-39 } \\
\hline BDI & $9.1 \pm 7.9$ & $12 \pm 7.3$ & -0.915 & 0.372 \\
\hline Digit Span Test & $6.2 \pm 1.3$ & $7.1 \pm 1.1$ & -1.724 & 0.103 \\
\hline STAI- (Stait Anxiety) & $36.1 \pm 11.1$ & $40.1 \pm 8.8$ & -0.960 & 0.351 \\
\hline STAI- (Trait Anxiety) & $39.6 \pm 8.6$ & $44.1 \pm 7.1$ & -1.370 & 0.189 \\
\hline IGT-Net 1 & $13.35(133.5)$ & $11.89(166.5)$ & -0.504 & 0.615 \\
\hline IGT-Net 2 & $10.6(106)$ & $13.86(194)$ & -1.162 & 0.245 \\
\hline IGT-Net 3 & $12.7(127)$ & $12.36(173)$ & -0.119 & 0.905 \\
\hline IGT-Net 4 & $9.9(99)$ & $14.36(201)$ & -1.547 & 0.122 \\
\hline IGT-Net 5 & $10.25(102.5)$ & $14.11(197.5)$ & -1.357 & 0.175 \\
\hline IGT-Net Total & $9.95(99.5)$ & $14.32(200.5)$ & -1.499 & 0.134 \\
\hline \multicolumn{5}{|l|}{ Over the age of 40} \\
\hline BDI & $8.3 \pm 7.6$ & $15.4 \pm 6.5$ & -2.078 & 0.056 \\
\hline Digit Span Test & $5.1 \pm 1.2$ & $6.4 \pm 1.5$ & -1.938 & 0.079 \\
\hline STAI- (Stait Anxiety) & $29.4 \pm 8.4$ & $40.9 \pm 7.2$ & -3.019 & 0.009 \\
\hline STAI- (Trait Anxiety) & $37.3 \pm 4.1$ & $47.6 \pm 9.2$ & -2.777 & 0.025 \\
\hline IGT-Net 1 & $10.15(101.5)$ & $7.36(51.5)$ & -1.141 & 0.254 \\
\hline IGT-Net 2 & $9.4(94)$ & $8.43(59)$ & -0.407 & 0.684 \\
\hline IGT-Net 3 & $7.6(76)$ & $11(77)$ & -1.402 & 0.193 \\
\hline IGT-Net 4 & $6.95(69.5)$ & $11.93(83.5)$ & -2.133 & 0.033 \\
\hline IGT-Net 5 & $9.85(98.5)$ & $7.79(54.5)$ & -0.878 & 0.380 \\
\hline IGT-Net Total & $7.95(79.5)$ & $10.5(73.5)$ & -1.032 & 0.315 \\
\hline
\end{tabular}

Abbreviations and Symbols: M: mean; SD: standart deviation; MR: mean rank; SoR: sum of ranks; $t$ : $t$ value for indepent sample $\mathrm{t}$ test; $\mathrm{Z}$ : $\mathrm{Z}$ value for Mann-Whitney $\mathrm{U}$ test 
BDI, DSFT, STAI and IGT scores of the recovered patients, which were measured at the initial and follow up phase, were compared in Table 3. There were no statistical differences between initial and one-month follow-up scores of the recovered patients.

The BDI, DSFT, STAI and IGT scores of the two groups are also compared by the participants' ages. In doing so, participants are distinguished into two groups as relatively young (aged 18 to 39 ) and relatively elder (aged 40 to 56). These age thresholds are determined by the Turkish IGT norm study (Icellioglu 2015). There were no significant differences in BDI, DSFT, STAI and IGT scores between relatively young participants of the recovered COVID-19 patients and healthy controls. On the other hand, state and trait anxiety scores and IGT-Net 4 scores of the healthy controls were higher than of the recovered COVID-19 patients (respectively; $\mathrm{t}=-3.019, \mathrm{p}=0.009 ; \mathrm{t}=-2.777$, $\mathrm{p}=0.025 ; \mathrm{Z}=-2.133, \mathrm{p}=0.033$ ) (Table-4).

\section{DISCUSSION}

To the best of our knowledge, this is one of the very few studies on cognitive and mental health aspects of COVID-19 sampling diagnosed patients. This research contributes to the literature by exploring how the pandemic influences psychological well-being and risktaking behavior tendencies. Specifically, our results suggest that recovered patients show high risk-taking behavior tendencies compared to healthy individuals. To support this, IGT-Net 4 scores show the significant difference and IGT-Net total scores were found to be marginally significant. Accordingly, the control group has higher state and trait anxiety levels than the recovered patients. The IGT scores were found to be similar in the 4-week follow up phase.

When we compare our findings with the Turkish norm study's data (Icellioglu 2015), recovered patients' IGT score was found to be similar to the normative data. Namely, the recovered patients' risk-taking behaviors may have been normalized because they overcome the COVID-19 threat. On the other hand, healthy controls seem to have a low tendency of choosing high-risk decks. This may be the result of continuing high COVID-19 threat for this group. Additionally, post COVID-19 neuropsychological deficits such as fatigue, cognitive disturbances may have affected the test performances of the recovered COVID-19 patients (Stam et al. 2020).

Many studies have reported that decision-making strategies are affected by anxiety levels. The effect of trait anxiety on IGT performance is indicated in the results of many researches (Maner et al. 2007, Miu et al. 2008, Peters \& Slovic 2000). Hereunder, the inverse relationship between anxiety level and high-risk decks was found out. This also may explain recovered patients' tendency of high risk-taking behaviors via their respectively lower level of anxiety. The underlying reason for these anxiety level differences may be the experience of overcoming the COVID-19 threat. Moreover, some studies have shown recovered patients produce antibodies and this may lead them to a favorable position in a reinfection circumstance ( $\mathrm{Ni}$ et al. 2020, Seydoux et al. 2020).

An interesting finding of the present study was both state and trait anxiety levels and IGT-Net 4 score found to be higher in relatively elders of healthy controls. On the other hand, anxiety levels and IGT scores did not differ in relatively younger individuals between the groups. Although COVID-19 can cause poor prognosis and mortality in younger people, higher complication or mortality rates of COVID-19 have been reported on elderly people (Guan et al. 2020, Ioannidis et al. 2020), and this may lead this kind of higher anxiety levels. Due to this high anxiety level and high risk of mortality, elderly healthy controls seem to have low risk-taking behavior tendencies.

Anxiety as a strong predictor of IGT performance shares this effect on people with HIV. These people with high anxiety levels show decision-making and IGT performance dysfunctions (Golub et al. 2016, Thames et al. 2012, Wardle et al. 2010). IGT is a highly valuable task in emphasizing brain structures for decision-making (Levy 2017, Li et al. 2020). These studies concurringly show a neural circuitry involving the dorsolateral prefrontal cortex, the insula and ventromedial prefrontal cortex, and any dysfunction of these regions show an effect on IGT performance. So, the epidemic may lead to these kinds of dysfunctions in the brain.

The present study is a descriptive experimental study which assessed the risk-taking behavior tendencies in recovered COVID-19 patients. These findings could inform other researchers seeking to understand the role of the COVID-19 epidemic on patients' decision-making abilities. However, the following limitations should be taken into account when interpreting our findings. Firstly, the sample size was relatively small, thus we might not have adequate support claims of having achieved valid conclusions. Secondly, the maximum age was relatively low in our sample when we consider the commonly specified high-risk age range for COVID-19 so we lack from this analysis. Thirdly, neuroimaging analysis needs to be done to specify the potential functional dysfunctions. Finally, we could not determine the anxiety levels and IGT performances throughout the disease. Therefore, longitudinal observations on the potential changes in these scores are suggested to be explored further.

\section{CONCLUSION}

In conclusion, our findings indicate that individuals who formerly diagnosed with COVID-19 are a more likely tendency to higher risk-taking behaviors. This can affect the recovered COVID-19 patients' behaviors such as wearing masks, respecting social (or physical) distance, and providing hygiene. 
Acknowledgments: None.

\section{Conflict of interest: None to declare.}

\section{Contribution of individual authors:}

Aslı Egeli, Serkan Adıgüzel, Ayşegül Yetkin Tekin \& Atilla Tekin conception and design of the study.

Aslı Egeli, Yaşar Kapıcı \& Bulut Güc: data collection.

Serkan Adıgüzel \& Ayşegül Yetkin Tekin: statistical analyses of data.

Serkan Adıgüzel \& Atilla Tekin: drafting of manuscript. All authors approved the final manuscript.

\section{References}

1. Bayar N, Sayll M: Brief report: Risk-taking behaviors in a non-western urban adolescent sample. J Adolesc 2005; 28:671-676

2. Bechara A, Damasio AR, Damasio H, Anderson SW: Insensitivity to future consequences following damage to human prefrontal cortex. Cognition 1994; 50:1-3

3. Bechara A, Damasio H, Tranel D, Damasio AR: The Iowa Gambling Task and the somatic marker hypothesis: some questions and answers. Trends Cogn Sci 2005; 9:159-162

4. Beck AT, Ward CH, Mendelson M, MockJ, Erbaugh J: An inventory for measuring depression. Arch Gen Psychiatry 1961; 4:561-751

5. Byrnes J. Changing views on the nature and prevention of adolescent risk taking: In: D. Romer (Ed.) Reducing adolescent risk: Toward an integrated approach. Thousand Oaks, CA: SAGE Publications, Inc., 2003

6. Giustiniani J, Joucla C, Bennabi D, Nicolier M, Chabin T, Masse C, et al.: Behavioral and electrophysiological arguments in favor of a relationship between impulsivity, risk-taking, and success on the iowa gambling task. Brain Sci 2019; 9:248

7. Golub SA, Thompson LI, Kowalczyk WJ: Affective differences in Iowa Gambling Task performance associated with sexual risk taking and substance use among HIVpositive and HIV-negative men who have sex with men. $J$ Clin Exp Neuropsychol 2016; 38:141-157

8. Guan WJ, Ni ZY, Hu Y, Liang WH, Ou CQ, He JX, et al.: Clinical characteristics of 2019 novel coronavirus infection in China. MedRxiv, 2020

9. Guven C: Reversing the question: does happiness affect consumption and savings behavior? J Econ Psychol 2012; 33:701-717

10. Haji Akhoundi F, Sahraian MA, Naser Moghadasi A: Neuropsychiatric and cognitive effects of the COVID-19 outbreak on multiple sclerosis patients. Mult Scler Relat Disord 2020; 41:102164

11. Hisli N: Beck Depresyon Envanterinin üniversite öğrencileri için geçerliliği ve güvenirliliği. Psikoloji Dergisi 1989; 7:3-13

12. Icellioglu S: Iowa Gambling Test: normative data and correlation with executive functions. Dusunen Adam 2015, 28:222

13. International Labor Organization. Monitor: COVID-19 and the world of work. Second edition: Updated estimates and analysis, 2020
14. Ioannidis J, Axfors C, Contopoulos-Ioannidis DG: Population-level COVID-19 mortality risk for non-elderly individuals overall and for non-elderly individuals without underlying diseases in pandemic epicenters. Environ Res 2020; 188:109890

15. Karakaș S, Yalın A: Görsel İșitsel Sayı Dizileri Testi B Formunun 13-54 yaş grubu üzerindeki standardizasyon çalışması. Türk Psikoloji Dergisi 1995; 10:20-31

16. Lazzari C, Shoka A, Nusair A, Rabottini M: Psychiatry in time of COVID-19 pandemic. Psychiatr Danub 2020; 30:229-235

17. Levy I: Neuroanatomical Substrates for Risk Behavior. Neuroscientist 2017; 23:275-286

18. Li S, Wang Y, Xue J, Zhao N, Zhu T: The Impact of COVID-19 Epidemic Declaration on Psychological Consequences: A Study on Active Weibo Users. Int J Environ Res Public Health 2020; 17:2032

19. Li X, Lu ZL, D'Argembeau A, Ng M, Bechara A: The Iowa gambling task in fMRI images. Hum Brain Mapp 2010; 3:410-423

20. Luo M, Guo L, Yu M, Jiang W, Wang H: The psychological and mental impact of coronavirus disease 2019 (COVID-19) on medical staff and general public - A systematic review and meta-analysis. Psychiatry Res 2020; 291:113190

21. Maner JK, Richey JA, Cromer K, Mallott M, Lejuez CW, Joiner TE, et al.: Dispositional anxiety and risk-avoidant decision making. Pers Individ Dif 2007; 42:665-675

22. Miu AC, Heilman RM, Houser D: Anxiety impairs decision-making: psychophysiological evidence from an Iowa Gambling Task. Biol Psychol 2008; 77:353-358

23. Ni L, Ye F, Cheng ML, Feng Y, Deng YQ, Zhao H, et al.: Detection of SARS-CoV-2-specific humoral and cellular immunity in COVID-19 convalescent individuals. Immunity 2020; 52: 971-977

24. Öner N, Le Compte A: Durumluluk-sürekli kaygl envanteri el kitabı, İstanbul, Boğaziçi Üniversitesi Matbaası, 1983

25. Peters E, Slovic P: The springs of action: affective and analytical information processing in choice. Pers Soc Psychol Bull 2000; 26:1465-1475

26. Seydoux E, Homad LJ, MacCamy AJ, Parks KR, Hurlburt $N K$, Jennewein MF, et al.: Analysis of a SARS-CoV-2infected individual reveals development of potent neutralizing antibodies with limited somatic mutation. Immunity 2020; 53:98-105

27. Sinanovic O, Muftic M, Sinanovic S: COVID-19 pandemia: Neuropsychiatric comorbidity and consequences. Psychiatr Danub 2020;32:236-244

28. Singh V, Schiebener J, Müller SM, Liebherr M, Brand M, Buelow MT: Country and sex differences in decision making under uncertainty and risk. Front Psychol 2020; 11:486

29. Spielberger CD, Gorsuch RL, Lushene RE: STAI Manual for the State-Trait Anxiety Inventory. Palo Alto, CA: Consulting Psychologists Press, 1970

30. Stam HJ, Stucki G, Bickenbach J: COVID-19 and post intensive care syndrome: a call for action. J Rehabil Med 2020;52:1-4

31. Thames AD, Streiff V, Patel SM, Panos SE, Castellon SA, Hinkin $\mathrm{CH}$ : The role of HIV infection, cognition, and depression in risky decision-making. J Neuropsychiatry Clin Neurosci 2012; 24:340-348 
32. Uludağlı NP, Sayll M: Orta ve ileri ergenlik döneminde risk alma davranışı: Ebeveyn ve akranların rolü. Türk Psikoloji Yazıları 2009; 12:14-24

33. Valdés-Florido MJ, López-Díaz Á, Palermo-Zeballos FJ, Martinez-Molina I, Martín-Gil VE, Crespo-Facorro B, et al.: Reactive psychoses in the context of the COVID-19 pandemic: clinical perspectives from a case series. Rev Psiquiatr Salud 2020;13:90-94.

34. Van Rheenen TE, Meyer D, Neill E, Phillipou A, Tan EJ, Toh WL, et al.: Mental health status of individuals with a mood-disorder during the COVID-19 pandemic in Australia: Initial results from the COLLATE project. $J$ Affect Disord 2020;275:69-77.

35. Wang C, Pan R, Wan X, Tan Y, Xu L, Ho CS, et al.: Immediate Psychological Responses and Associated Factors during the Initial Stage of the 2019 Coronavirus Disease (COVID-19) Epidemic among the General Population in China. Int $J$ Environ Res Public Health 2020;17:1729

36. Wang C, Pan R, Wan X, Tan $Y, X u$ L, McIntyre RS, et al.: A longitudinal study on the mental health of general population during the COVID-19 epidemic in China. Brain Behav Immun 2020; 87:40-48

37. Wardle MC, Gonzalez R, Bechara A, Martin-Thormeyer EM: Iowa Gambling Task performance and emotional distress interact to predict risky sexual behavior in individuals with dual substance and HIV diagnoses. J Clin Exp Neuropsychol 2010; 32:1110-1121

38. Wechsler D: The measurement and appraisal of adult intelligence. Baltimore, MD: The Williams \& Wilkins Company, 1939

39. World Health Organization: Coronavirus disease (COVID19) Situation Report-209.https://www.who.int/docs/defaultsource/ coronaviruse/situation-report/20200816-covid-19sitrep-209.pdf?sfvrsn=5dde1ca2_2, 2020

40. Yang H, Ma J: How an epidemic outbreak impacts happiness: factors that worsen (vs. Protect) emotional wellbeing during the Coronavirus pandemic. Psychiatry Res 2020; 289:113045

41. Zhou H, Lu S, Chen J, Wei N, Wang D, Lyu H, et al.: The landscape of cognitive function in recovered COVID-19 patients. J Psychiatr Res 2020; 129;98-102

Correspondence:

Atilla Tekin, MD

Psychiatry Department, Faculty of Medicine, Adryaman University

Adryaman, Turkey

E-mail:md.atillatekin@gmail.com 